\title{
Establishing the costs of poor green space management: mistrust, financing and future development options in the UK
}

\author{
lan Mell* \\ University of Manchester
}

\begin{abstract}
The ongoing austerity programme of the current UK government is placing stresses on Local Planning Authorities (LPAs), as they attempt to deliver statutory and discretionary services. As a discretionary service, green space provision has been identified as a service that can be cut to balance the accounts of many LPAs. The following article assesses local government, business and residential communities, and environmental stakeholder responses to green infrastructure funding. It comments upon the politicisation of landscape management, and illustrates the mechanisms available to advocates to adopt alternative approaches to financing. Reflecting on a series of case studies from England the article examines innovative practice, as well as identifying where conflicts remain. The article concludes that rethinking existing funding mechanisms is essential to establish a viable economic model for funding green spaces in the future.
\end{abstract}

Keywords: Green space, local government, public perception, development options, financing.

\section{Introduction}

The funding of landscape resources by Local Planning Authorities (LPAs) has traditionally been attributed with secondary importance compared to the provision of housing, social infrastructure and economic development. As Walmsley (2006: 257) stated: "green space is something nice to have". Within the environment sector there has been ongoing debate regarding how best to communicate the added value that green spaces deliver to decision-makers, the economic and real estate development sectors, and the public. Marginalisation of the environment at the expense of economic growth has led many commentators to question the government's awareness of the ecological and socio-economic benefits associated with landscape resources (Kambites and Owen, 2006; Selman, 2009). As central government has systematically cut LPA core budgets post-2010 following the creation of the Conservative-Liberal Democrat coalition government, such discussions have become more acute (Mell, 2017). 
p. 138. Establishing the costs of poor green space management: mistrust, financing and future development options in the UK

To address the ongoing marginalisation of core funding, LPAs have increasingly examined how they finance green space management, ${ }^{1}$ and explored alternative sources of capital and revenue income to fund provision (Clarke and Cochrane, 2013). As a consequence, several core cities in England are reconsidering what green space resources they will fund, what they can afford to fund, and whether they can identify more diverse income streams to meet these financial commitments in the future. To date this has met with varied success, as LPAs continue to assess the "value" of their green space assets and consult with partners, including the public, regarding changes in management. It remains unclear, however, whether alternative and sustainable sources of funding can be generated to fund green space management (Martin et al., 2016; O'Brien and Pike, 2015).

The central issue that this article examines is this variability of approaches taken by LPAs to the ongoing financial constraints placed on green infrastructure by austerity. The discussion presented focuses on funding options being discussed by LPAs as alternatives to central government allocations, explores what options are being debated, and how cities are taking these ideas forward. To date there has not been a detailed examination articulated within academic literature focusing on the different funding mechanisms being discussed in LPAs, although several third and environmental sector organisations including Nesta (2016) and the Heritage Lottery Fund (2016) have reported on the impacts of these decisions. To provide added clarity, the following examines where LPAs have made progress in identifying alternative funding mechanisms, where barriers hinder their use and argues for greater knowledge exchange to help resolve these issues. The article presents an analysis of the discussions and evidence influencing LPA decision-making related to green space funding. Moreover, it brings together analysis derived from reflective engagement with the process by the author alongside discussions with academics, LPAs, the public, community/environmental organisations, and local media representations of funding to shape the debates presented. The article concludes by proposing a rethinking of existing understandings of financing, and the mechanisms through which we fund green space, arguing that this is essential if we are to establish sustainable financial models to fund landscape management. It also suggests that despite the significant problems caused by ongoing austerity LPAs may benefit in the long-term, as they are engaging with a broader range of funding options drawn from public, private and community sources which may be more resilient to fluctuations in central government funding.

\section{The impacts local government austerity in the UK}

Since 2010, following the formation of the Conservative-Liberal Democrat coalition government and thereafter the Conservative (2015-17), and minority Conservative (with the Democratic Unionist Party, 2017 onwards) administrations, the UK government has promoted an austerity drive to rebalance the finances of the UK following thirteen years of New Labour government (1997-2010) (Lowndes and Gardner, 2016; Kennett et al.,2015). Under New Labour spending on public service provision increased with significant expansions of adult social care, children's services, planning and development activities, and funding for environmental management (Marshall, 2009). Cuts to the core funding of local government post-2010 could, therefore, be seen as both a rebalancing of public service expenditure and an ideological shift away from the more socially minded New Labour ${ }^{2}$ administration towards the reassertion of a market-led approach to government (Bentley and Pugalis, 2013). 
p. 139. Establishing the costs of poor green space management: mistrust, financing and future development options in the UK

Post-2010 funding measures have placed severe stresses on LPAs, as they try to deliver statutory and maintain discretionary services. Unfortunately, many LPAs across the UK have found this problematic (Mell, 2017), with public reactions to service cuts reported in the UK media as being negative, and in many places emotive (Broomfield, 2017; Plimmer, 2016; Taylor, 2018). However, these reactions have not slowed the cuts, with LPAs continuing to seek financial equilibrium between income from local taxation and grants, and development and expenditure. Furthermore, although local government officers have worked extensively to find savings, there remains a view within local government that service provision should be maintained (Lowndes and Pratchett, 2012). Due to the breadth of cuts this has not been possible and the funding of libraries, children's activity and care centres, and sports provision has decreased. This has raised concerns regarding whether any non-statutory services will be protected if the stresses placed on existing funding mechanisms continue (Gainsbury and Neville, 2015; Local Government Association, 2014).

Within these discussions environmental advocates have become increasingly vocal in establishing the "value" of green space (Mell, 2015). The provision of high quality and free to access public green space has a long history in the UK. Moreover, through the promotion of new Garden Cities and the Sustainable Communities programme, the UK government, LPAs and environmental advocates have promoted the core principles of green infrastructure: ${ }^{3}$ connectivity, access to nature, multi-functionality and the delivery of socio-economic and ecological benefits within planning (Howard, 2009; Mell, 2016). Although there is a corresponding evidence base which promotes the value of green infrastructure for society, there remains a proposition that public and private stakeholders only become aware of the benefits that the environment provides when these resources are threatened (Roe and Mell, 2013; Wolch, Byrne, and Newell, 2014). However, an extensive literature also exists reflecting the ways individuals and communities attribute value to green infrastructure that are often overlooked in LPA decision-making (Jerome, Mell, and Shaw, 2017). Furthermore, academic and practitioner research is being used by environmental, third-sector and academic advocates to illustrate the socio-ecological value of green spaces to health and wellbeing (Pretty et al., 2007), flood and climate change mitigation (Gill et al., 2007) and economic prosperity (Ecotec and Sheffield Hallam University, 2013). This literature argues that access to high-quality landscapes or recreational spaces located proximate to homes and places of work have significant impacts on both quality of life and economic prosperity compared to locations with high proportions of grey infrastructure 4 (Meerow and Newell, 2017; Tzoulas and James, 2010). However, it also recognises that additional factors including density and the mix and type of built infrastructure influence these conversations (Gaffikin, Mceldowney and Sterrett, 2010; Naylor et al., 2017). The economics of investment in green infrastructure thus remain subject to change and, as such, the 'value' of green spaces has been downplayed by government, LPAs and other stakeholders in some locations (Mell, 2017).

\section{Changes to landscape and green space planning in the UK post-2010}

This article takes 2010 as a starting point for the discussion of green infrastructure financing as it kick-started the move to a more devolved form of local governance via the 2011 Localism Act (Department of Communties and Local Government, 2011) and the release of the National Planning Policy Framework (Department of Communities and Local Government, 2012), which facilitated a significant shift in the emphasis of LPA funding and responsibility for the delivery of service provision in the UK to the local (Lord and Tewdwr-Jones, 2014). As a discretionary service, green spaces have been identified as an area where budgets can be reduced in order to balance LPA finances. 
p. 140. Establishing the costs of poor green space management: mistrust, financing and future development options in the UK

In contrast, funding for environmental management under New Labour offered more support for green infrastructure than the current administration, although this was linked to a promotion of "place competitiveness" and regional entrepreneurship (Thomas and Littlewood, 2010: 203). However, critiques of New Labour have argued that the expanding commercialisation of green spaces during their tenure was part of their neo-liberalisation of public services (Allmendinger, 2011). Significantly though New Labour provided resources promoting England's Community Forest programme (England's Community Forests, 2004), the Countryside Agency's "Countryside in and Around Towns" mandate (Countryside Agency and Groundwork, 2005), and the "Sustainable Communities" programme (Department of Environment Transport and the Regions, 1999; Office of the Deputy Prime Minister, 2002). This facilitated greater discussion between LPAs and the environment sector, and increased the influence of organisations such as Natural England and the Environment Agency within local environmental decision-making. Thus, while the post-2010 governments have been considered to be "rolling back state infrastructure" through devolution of authority to the local (Lord and Tewdwr-Jones, 2014: 354), New Labour facilitated broader discussions between stakeholders which shaped planning policy formation and green infrastructure investment (Mell, 2015).

This process generated growing recognition within LPA policy-making that planning for landscape enhancement could have a positive impact on the development of more sustainable, liveable and resilient cities, as discussed in New Labour's Sustainable Communities programme (Raco, 2005). This was evidenced in what Mell (2016: 36) calls the 'expansion' phase of green infrastructure planning, which saw an increased number of Local Development Framework (LDF) documents making reference to green infrastructure to meet health, economic and climate change objectives (Lennon, 2014), green infrastructure strategies being produced (for example by the Mersey Forest, 2013), and most pertinently, green infrastructure being embedded within developing Regional Spatial Strategies (RSS) (McGuinness and Mawson, 2017). The latter promoted green infrastructure as a strategic priority, and enabled LPAs to identify corresponding opportunities for the funding and management of landscape resources (Horwood, 2011). However, post-2010 and the revocation of RSSs and the subsequent reductions to LPA budgets green infrastructure thinking has focused more directly on central government policy objectives: in particular health and well-being, flooding/stormwater management and economic development (Mell, 2010; Sinnett et al., 2015).

Due to ongoing policy changes, LPAs have re-examined what they can deliver with consideration to their statutory duties within the NPPF. Currently, there are no legal requirements to fund green infrastructure. As a result, some LPAs have limited their financial support for environmental management. However, the extent of the cuts has led to greater restrictions being placed on allocations leading to what Butler (2018b) calls 'territorial injustice' in service provision. Even in locations where the business case for green infrastructure is deemed positive, such as London and Glasgow, there remain limitations on what LPAs can fund (Greater London Authority, 2016). Consequently, although the development of guidance and strategies under New Labour - for instance in Manchester and Merseyside - positioned green infrastructure in decision-making conversations it has not transitioned into being a political priority in all areas due to the continued need for LPAs to deliver housing and other commercial and built infrastructure (Department of Communities and Local Government, 2012; Mell, 2017). Questions therefore remain as to how LPAs can balance investments in green infrastructure when they are deemed secondary to other forms of infrastructure, such as housing, roads or commercial property? 
p. 141. Establishing the costs of poor green space management: mistrust, financing and future development options in the UK

Consequently, we could consider green infrastructure funding to be in a "financial limbo" in the UK, where LPAs are legally obliged to deliver services despite diminishing finances. Moreover, although, the Department for Environment, Farming and Rural Affairs (2018) is supportive of investment in landscape enhancement, the Treasury, and the Ministry of Housing, Communities and Local Government (MHCLG, formerly the Department for Communities and Local Government) continue to promote austerity and further deregulation of planning to reduce perceived limits placed on development (Lord and Tewdwr-Jones, 2014). It therefore continues to fall to advocates including England's Community Forest Partnerships, Natural England, and the Wildlife Trusts to facilitate changes of approach to green infrastructure funding that engages LPAs and promotes the identification of long-term solutions to funding shortfalls.

\section{Promoting "green infrastructure" planning in funding and management discussions}

The changes in UK central government financing have necessitated rethinking how green infrastructure can be, and is, funded. This has led local government officers to reconsider what services they can deliver, to what level, and how this impacts on public perceptions of the landscape. In some cases, this has facilitated more innovative discussion between LPAs and other stakeholders from the private and environment sector which have identified alternative funding options, such as the Glasgow and Clyde Valley Green Network Partnership (Hislop and Corbett, 2018). Other areas, for example Northamptonshire, have withdrawn service provision as they do not have the capacity or partnerships to facilitate comparable delivery (Butler, 2018a; Caller, 2018) Variations of this nature illustrate a cleavage between LPAs' funding and service provision that is acutely political, especially if we view decision-making as a process that assesses the needs/aspirations of local electorates against strategic investments to facilitate balanced approaches to development. Party politics may shape this process in different ways across the UK (Tewdwr-Jones, 2012), with a significant number of LPAs continuing to under-resource green infrastructure. Subsequently, green infrastructure is not always thought of as a political priority, especially in areas where housing, social service provision and economic development take precedence such as the former industrial cities in the Midlands and north of England. ${ }^{5}$

One significant aspect impacting decision-making within LPAs is the role of advocacy between local government and environmental and community stakeholders (Kambites and Owen, 2006; Lennon et al., 2015). Over the proceeding decade (2005 onwards) significant progress was made in developing consensus between green infrastructure advocates ${ }^{6}$, LPAs, and other stakeholders regarding the added value that green infrastructure can deliver. This has been led by organisations, such as the Community Forest partnerships, who have worked extensively with LPAs, communities and business partners to deliver landscape enhancement (Blackman and Thackray, 2007). Such work has generated 'buy-in' in many areas of the private and community sectors facilitating further engagement with green infrastructure planning (Mell, 2014). More recently, Business Improvement Districts (BIDs) and other private sector organisations including developers/construction companies have started engaging with green infrastructure funding to (a) deliver their planning obligations, ${ }^{7}$ (b) gain planning consents, (c) engage in Corporate Social Responsibility (CSR) activities (Naumann et al., 2011). Whilst this has reduced the financial pressures placed upon LPAs it has also reinforced a disjuncture within funding/management conversations (De Magalhães, 2012; Ward, 2006), whereby: 
p. 142. Establishing the costs of poor green space management: mistrust, financing and future development options in the UK

1. Collaboration and investment from non-traditional sources is an essential alternative to limited funding providing LPAs with additional opportunities to develop partnerships and meet the financial needs of green space service provision (Mell, 2016).

2. Allowing private business to fund green infrastructure creates a potential imbalance, as many commentators argue that such funding should be the responsibility of LPAs and that by engaging corporate sponsors creates an environment of mistrust, where funders are considered to receive preferential treatment for future development (Tait, 2011).

The latter position is visible in parts of the UK where developers are deemed to have extensive influence over LPAs in terms of what development is permitted (Tait, 2011). This is particularly acute in discussions of housing development on green infrastructure, as there is a significant body of academic and practitioner research which argues that addressing the ongoing 'housing crisis' should take precedent over the protection of urban green spaces or green belt land (Papworth, 2015; Lally, 2018). For example the Park Road amenity green space/Sefton Park Meadows area of Liverpool was identified as a location for executive housing in a city that potentially struggles to allocate sufficient sites to meet its five-year housing supply targets (Liverpool City Council, 2016; Thorp, 2018). It can be argued that a fine line exists between promoting effective collaboration and providing favourable conditions for developers. However, this article suggests that there was greater movement towards better understanding of the benefits of collaboration and partnership during the New Labour administration than post-2010 (Lowndes and Gardener, 2016), even if this facilitated an increased commercialisation of public services and assets (Allmendinger, 2011).

To date no overarching approach to ensure long-term funding for green infrastructure has been agreed. Alternatively, LPAs have engaged in exploratory processes of examining how various public, private and community-led mechanisms can be used to meet financial obligations. This highlights the complexity of financing and also offers insights into the complementarity between local government and public-private-community stakeholders in their engagement with these discussions.

\section{Methodology}

This article used a mixed-methods approach to collect date on the impacts of austerity on LPA funding for green infrastructure. Drawing on expert interviews with planners, green infrastructure specialists, local government officers and developers, observations undertaken at consultations, public and council meetings, discussions with the public, and content analysis of local media articles aids the presentation of the variability of these debates by LPAs and stakeholders dealing with green space financing/management. This process was undertaken over an extended period, 20152018 , to trace the development of funding discussions and the subsequent changes made in LPA actions. Specifically the article draws on evidence from:

1. Author engagement as a Board Member of the Mayoral Commission 'Liverpool Green and Open Space Review" (LG\&OSR) over a 24-month period (2015-16) working with public-private-community stakeholders to assess the state of Liverpool's green infrastructure, how it could be funded, and reporting to the Mayor's Office of Liverpool City Council (LCC). This used in-situ observations and discussions with public, private and LPA stakeholders, to generate data. 
p. 143. Establishing the costs of poor green space management: mistrust, financing and future development options in the UK

2. Interviews and discussions with planners, Business Improvement District (BID) officers, developers and environmental sector representatives in London in 2018. Facilitated by the Valuing Nature fund 8 this evidence draws on engagement with stakeholders and worked with the Greater London Authority (GLA) as a key gatekeeper. A total of eighteen interviews were conducted with stakeholders focussing how different organisations addressed what and how green infrastructure was funded. The data was interrogated using thematic analysis based on an extensive review of the key arguments made in the research/practitioner literature. This analysed the use and discussion of funding bodies, projects, collaborations, barriers and successes to delivery, government policy, and local planning contexts to debate the current and future funding options open to different organisations.

3. Ongoing discussions with academics researching planning/environmental issues in Sheffield and Newcastle allowing the author to analyse professional assessments of the actions and responses to Gl funding, and its impacts from an academic perspective.

4. A reflection of media coverage (online and print) regarding funding of green infrastructure from 2015 onwards. This was undertaken via a non-systematic review of media reporting of the funding of green infrastructure, LPA decisionmaking and local responses. ${ }^{9}$

The use of a mixed-methods approach was deemed critical to the development of a more in-depth understanding of the factors influencing green infrastructure funding by different LPAs. It is, however, acknowledged that the scope, type and nature of information presented in this article vary. Partly this reflects the ways LPAs debate funding (internally and in public forums), as they do not use a singular approach when communicating these issues. Secondly, the data was generated via existing and subsequently extended professional and stakeholder networks rather than using a systematic sampling of professionals or public-private stakeholders working in the field. Consequently, whilst this provides evidence of the nuances of the discussions being held in and between LPAs, it also limits the ability to triangulate information in a more rigorous manner. Thus, the article takes a more reflective stance that utilises a range of data sources and employs its analysis to identify where supportive or challenging issues exist in the funding of green infrastructure.

The cities of Liverpool, Newcastle, Sheffield, and London have been exploring a range of public, private and community-led approaches to green space funding and have examined areas of innovation, best practice, and barriers to the effective management of green infrastructure. The four cities discussed were selected as they represent front-runner locations subject to the stresses of austerity financing, and have been working to identify alternative funding sources to meet the financial requirements of green infrastructure management. Each location is subject to varying development pressures, and has engaged in different ways with the political debates surrounding green infrastructure pre- and post-2010. LPAs in each area have also engaged with non-LPA stakeholders from the environment, third, business and development sectors to identify alternative funding streams. These four cities are not representative of the funding pressures placed on all LPAs in the UK: for instance they do not necessarily reflect discrepancies in urban/rural policy focus, type of LPA structure, or location within the UK (England vs. the devolved administrations of Scotland, Wales and Northern Ireland). However, they are cities at the forefront of discussions (along with Bristol and Birmingham) exploring how best to fund landscape management in England. From the discussion presented in this article it is envisaged that, in subsequent evaluations, approaches to funding can be transposed to other cities in the UK experiencing comparable financial constraints. 
p. 144. Establishing the costs of poor green space management: mistrust, financing and future development options in the UK

\section{Current local government approaches to financing green infrastructure}

To examine the impacts of austerity on green infrastructure management the following section discusses examples where changes in funding, political support, and advocacy are visible.

\section{Liverpool}

From 2015 onwards, Liverpool City Council (LCC) has been involved in a process of rationalisation of funding for non-statutory services. LCC has lost approximately 58 per cent of its core budget and has responded by undertaking a review of its service provision to identify savings. This process was integral to the formation and delivery of the Liverpool Green and Open Space Review (LG\&OSR) (Liverpool City Council, 2016); a Mayoral Commission established to evaluate the social and economic benefits of maintaining green infrastructure in Liverpool. Its establishment was linked directly to the perceived lack of protection that Liverpool's green spaces were afforded following the submission of a series of high-profile planning applications to develop housing, commercial and sporting infrastructure on green spaces across the city (Liverpool Echo, 2015a, 2015b). A key driver in the formation of the LG\&OSR was the level of criticism received by LCC over these cases, including ongoing community campaigns to halt development.

Attempts to address funding cuts led directly to renegotiation of the city's Service Level Agreement (SLA) with its landscape contractors. However, as the LG\&OSR developed it became apparent that LCC did not hold an up-to-date evaluation of the city's green infrastructure. Consequently, the review was used to raise awareness of the extent, state and location of green infrastructure. This lack of awareness was addressed through consultation, with significant numbers of the public and community groups engaged highlighting where they attributed value to local and city-scale green spaces. The review also enabled LCC to take stock of its existing green infrastructure funding mechanisms, and identify options for future provision.

The LG\&OSR centred on establishing clarity within LCC of the location, state and value of green infrastructure supported by public commentary. In addition, and potentially most importantly, the process enabled LCC to reconsider the range of public, private and community led funding options available for green infrastructure. This included reflecting on how community asset transfers could be used to manage green infrastructure (and included discussions of how to generate the capacity to do so), and prompted an investigation into how business could be more effectively engaged in paying for green infrastructure. Proposals were also made to explore the potential role of the city's civic institutions: universities, the emergency and health services, and football clubs, in delivering landscape improvements and/or management.

To date the uptake of green infrastructure by these organisations has been moderate, however, establishing the parameters to facilitate engagement with these conversations, via the LG\&OSR, shows a commitment to dialogue. Ongoing discussions pertaining to the protection/development of Sefton Park, Newsham Park and Walton Hall Park illustrate this (Houghton, 2018; Thorp, 2018). Moreover, the LG\&OSR increased awareness of potential commercial opportunities ${ }^{10}$ and identified key locations (Sefton and Calderstones Parks) where greater commercial activities could be pursued. One of the review's key findings was the promotion of a Parks Trust financing model, which generated significant debate within LCC and consultees but has, to date, not moved beyond initial discussions. There remains a reluctance to formally adopt this approach, as it would require an endowment fund to be established supported by LCC 
p. 145. Establishing the costs of poor green space management: mistrust, financing and future development options in the UK

finances, private sponsorship, potential land sales, and commercialisation; none of which have been agreed. ${ }^{11}$ Nevertheless, there have been positive outcomes from the LG\&OSR. Its discussion of strategic landscape opportunities has been used within the latest Local Plan consultation in 2016 to shape the identification of potential investments sites and has helped LCC to align these projects/sites with requests for planning gain/consent payments. The LG\&ORS has also acted as a vehicle to facilitate conversation with LPAs in Sheffield and Newcastle regarding applications to the HLF/National Trust Parks Accelerator Fund, and helped LCC engage with an EU-funded Horizon 2020 project focussing on investment in Nature-Based Solutions (NBS). ${ }^{12}$

\section{Newcastle}

The ongoing limitations placed upon Newcastle City Council's (NCC) budget have seen it explore several options to fund statutory and non-statutory services. Since 2010 Newcastle's parks budget has been cut by approximately 91 per cent (Duncan and Hussain, 2017b). This has required NCC to explore a range of proposals including the release of land within the city's Green Belt for development. They have also discussed rationalising landscape services to lower costs, charging for events and parking in city parks/green spaces, and the sale of land holdings to developers would (Seddon, 2017). Several of these proposals have been poorly received by local citizens. More specifically a prominent proportion of local opinion has stated that green spaces should not be sold even where limited funding could undermine its future quality and integrity (Henderson, 2017). To address this, in November 2017 the City Council's Cabinet approved plans for the establishment of a Charitable Parks Trust. ${ }^{13}$ The proposals for the Parks Trust would see NCC investing $£ 9.5$ million over a ten-year period to enable the Trust to manage 51-hectares ${ }^{14}$ of the city's green infrastructure (Duncan and Hussain, 2017a). NCC was able to draw down $£ 237,500$ in transitional funding from the HLF to develop the parameters of their Parks Trust (Cosgrove, 2017).

Subsequently, NCC have progressed through a process of due diligence regarding the costs and potential impacts of commercialising or the sale of its parks on capital and revenue budgets. NCC was also required to examine the legal requirements, for example covenants placed on the city's landscape that need to be considered within the management of the Parks Trust. This has subsequently been discussed within NCC's Scrutiny Committee to ensure that the perceived negative impacts related to the sale of parks/green spaces were examined (Holland, 2018). The proposals to establish a Parks Trust were widely castigated in local media outlets by journalists and local residents (Henderson, 2017), although the level of scrutiny applied coupled with the support of the HLF and National Trust appears to have established a financially acceptable rationale for the Trust, which is deemed politically workable to NCC.

\section{Sheffield}

Like Newcastle and Liverpool, Sheffield City Council (SCC) has been subject to significant cuts in its core budget ( $£ 350$ million between $2011-17$, and a proposed further $£ 40$ million in 2018/19) (Sheffield City Council, 2017). However, from 2015 onwards SCC have been engaged in conversations with other core cities and the National Trust to investigate the viability of establishing a city-wide Parks Trust to secure long-term funding for the city's green infrastructure. ${ }^{15}$

As part of this process the National Trust worked with economists to develop a National Capital Account (NCA) for Sheffield. This assessed the value of the city's green and open spaces at $£ 1.2-1.3$ billion, which differs from the current figure of a $£ 16$ million funding liability shown in SCC's budget (Vivid Economics, 2016). This figure 
p. 146. Establishing the costs of poor green space management: mistrust, financing and future development options in the UK

covers a number of benefits related to health, recreation, flooding and climate control, which are not always taken into consideration on balance sheets. In addition, the National Trust has argued that for every $£ 1$ spent on parks, society receives a $£ 34$ return (of which 60 per cent relates to physical and mental health) (Vivid Economics, 2016). Establishing this economic rationale for maintaining green space was used to support the creation of a city-wide Parks Trust managed by the National Trust in order to remove the financial liability for maintenance from SCC. However, this process has stalled partly due to fears that the National Trust may overly commercialise a significant proportion of the city's parks or that it may prioritise "prime" sites to the detriment of other locations. One alternative to a Parks Trust is the Heeley Park Subscription project which, funded with $£ 97,890$ from Nesta, HLF, and the Big Lottery Fund (BLF), is evaluating the long-term potential of a parks subscription fee for local residents and businesses to fund the management of the park in the long-term (Nesta, 2018).

A further area that has seen significant discussion regarding the funding of Sheffield's green infrastructure has been the ongoing public works contract between the city and a private contractor to manage the city's tree stock. ${ }^{16}$ The contract was let to help rationalise the city's tree management and highways maintenance using a Private Finance Initiative (PFI), which helped SCC leverage central government funding for road/pavement improvement works. The agreement enabled SCC to use a single contractor to plan and deliver refurbishment of the city's highways and management of its street trees (Highways, 2012). The framing of the contract has, though, allowed the contractor to undertake tree felling within their service agreement due to its terms of reference ${ }^{17}$ leading to significant local and national opposition and protest (Moore, 2017; Torr, 2018). This has led to increased costs for the council due to added security, legal fees and additional interest on borrowing required during the extended tree works, and growing unrest from local communities who view the works as impacting upon their quality of life and physical environment unnecessarily (Burn, 2017; Torr, 2018). Although there are financial and legal justifications for working with a single contractor, namely cost and simpler communication/negotiation, the application of the service agreement has created mistrust between the city, its communities and the contractor, which may hinder future discussions of green infrastructure funding (Perraudin, 2018). Furthermore, there is a view within the city's campaign groups, for example the Sheffield Trees Action Group (STAG), that the climatic and ecosystem service benefits of the city's trees are not being considered when tree felling is undertaken. At the time of writing the PFI contract remains live and the risk of further tree feeling remains a significant political issue within Sheffield.

\section{London $^{18}$}

According to some commentators, the provision of green infrastructure (and other public services) in London is better able to withstand the pressures placed on LPA budgets by austerity and may even lead to a 'bounce forward' in terms of delivery (Fitzgerald and Lupton, 2015). Due to the wealth of green space, approximately 47 per cent of its land cover, and the links between provision, management and quality associated with the city's royal parks, the Queen Elizabeth Olympic Park, and its economic prosperity many question whether London has been impacted by funding cuts. However, due to its governance structure of thirty-two independent Borough Councils, the City of London Corporation, and the Greater London Authority (GLA), there are competing interests regarding the funding and management of green infrastructure (Greater London Authority, 2015). Furthermore, the core funding received by each LPA has been cut, as in other parts of the UK, since 2010 (Eichler, 2018). This has led 
p. 147. Establishing the costs of poor green space management: mistrust, financing and future development options in the UK

London's LPAs to reassess the value of their landholdings and commercial assets and explore how best to manage or monetise these.

London is, however, in a unique position compared to England's core cities in dealing with austerity. Due to the rate of construction, demographic change, and the cost of real estate, its LPAs are not restricted in the same ways as in other parts of the UK in terms of attracting and approving developments. Although they are subject to pressures in delivering economic development, investment in transport and affordable housing within their local development plans, negotiations with developers and subsequent releases of funding in the form of S106 Planning Gain and Community Infrastructure Levy (CIL) payments or capital grants for investment in built and green infrastructure service provision are more frequent. However, the outcome of such practices remains variable. Moreover, there is growing awareness within the development sector that green infrastructure can be a commercially viable form of investment, as several major construction companies are integrating urban greening into their site plans as a first principle of development: see, for example, Grosvenor's (2015) 'Living Cities: Our approach in practice'.

Moreover, the GLA, LPAs and other stakeholders have been successful in generating buy-in for green infrastructure from non-traditional stakeholders. There is a growing interaction between environmental and third sector organisations such as Thames21, Trees for Cities and businesses across London to deliver corporate social responsibility (CSR) programmes that provide revenue for landscape projects through volunteering but also increasingly capital financing (Thames21, 2016). This is viewed by businesses as a way of giving back to London's communities and improving the quality of life for residents, their businesses, and their employees. In addition, through investment in landscape enhancement businesses and LPAs have been able to market London as a green, sustainable and liveable city. The Corporation of London has been a key exponent of this view, and is working with landholders to ensure businesses do not relocate outside of London due to Brexit. Improvements in streetscapes, the greening of development sites, and local park enhancements are three ways that the Corporation of London has helped facilitate capital investment in green infrastructure. It has also placed significant emphasis on the commercialisation of its land holdings, including Epping Forest and Hampstead Heath, as a mechanism to generate income and underwrite the funding and management of its green infrastructure portfolio.

We can also identify growing engagement with green infrastructure from some Social Housing providers who are working with communities and the environment sector to improve the quality and quantity of green space in high-density areas. Bodies such as the Peabody Trust in Thamesmead are working with utility, transport and development organisations to generate funding to ensure that its landholdings remain resilience to climatic and socio-economic change (Cosgrove, 2018). ${ }^{19}$ Finally, several of London's Business Improvement Districts (BIDs), including those in Victoria, Bankside and Thames Bridge, have worked with businesses, communities and utility providers to increase London's landscape functionality via investment in sustainable drainage, street trees and community gardens. BIDs have been successful in generating buy-in for the delivery of green infrastructure because they can provide a more robust economic case for investment to local businesses compared to LPAs. BIDs are also trusted entities within the business community deemed able to effectively forecast the economic benefits associated with investment in urban landscapes (Lloyd et al., 2003). This includes over $£ 4.3$ million of private sector investment in green infrastructure from BIDs in central London (figures correct up to 2016: Cross River Parnership and Natural England, 2016). However, it is also recognised that (a) not all businesses are supportive of funding green infrastructure and (b) that the primary aim of BIDs is to increase economic returns. Thus, although landscape enhancement to improve the 
p. 148. Establishing the costs of poor green space management: mistrust, financing and future development options in the UK

liveability and climatic quality of London is presented as a goal of several BIDs, they are also working with business stakeholders to increase individual areas' economic growth.

\section{Discussion and conclusion}

The discussion presented above highlights the variability in approaches taken by LPAs in their thinking regarding green infrastructure funding. This has illustrated the difficult decisions that LPAs are being forced to make in their attempts to balance budgets (Wilson and Hughes, 2011). The outcome has been a nationwide process of rationalisation, whereby LPAs have assessed the viability of delivering statutory, as well as non-statutory, services. In many locations that has led to withdrawing funding from non-statutory services such as parks and green spaces (Lowndes and Gardner, 2016). This has led to significant public unrest and increased debate regarding the most effective ways to promote economic growth, maintain urban liveability, and fund landscape management.

LPAs in the UK have, individually and collectively, engaged in processes of rationalisation regarding their legal, financial and institutional capacity to deliver green infrastructure. This has promoted wider debate about how and what green infrastructure should be funded and included reflections on the role of both traditional and non-traditional stakeholders in meeting capital and revenue needs. Subsequently, we can identify a growing diversity of actors providing funding for and management of green infrastructure. From the four examples discussed we can identify a trend of decreasing LPA funding, whilst simultaneously noting growth in project work, grant funding and volunteering from the environment and private sector. Although these alternative income streams do not match central government funding they provide LPAs with options to help address shortfalls. However, the process of engagement and negotiation required to facilitate private or environmental sector financing is lengthy and variable; it is not a "quick fix" for funding (Mell, 2017).

The establishment of a broader suite of financing options for green infrastructure therefore remains problematic for LPAs. Their ability to generate buy-in from businesses, the environment/third sector and the public has been difficult due to the emotive nature of parks and green space management (Wilson and Hughes, 2011). However, within each of the four locations discussed we can identify options where LPAs and their delivery partners have effectively identified new sources of income to meet green infrastructure's financial needs. This includes embedding rationales for green space funding in local planning documents, for example: the Liverpool Local Plan (2016) consultation, working with the HLF and National Trust to explore the value of a Parks Trust; Newcastle's development of a commercialisation strategy for parks; the promotion of BIDs as facilitators of green infrastructure funding in London; and the Nesta/HLF/BLF supported subscription project in Sheffield's Heeley Park. However, within this suite of options there is an inherent complexity regarding the differences between capital and revenue funding, maintaining public access within commercialised activities, and ensuring that the quality of a city's green infrastructure remain when different funding and management regimes are employed (Mayor of London, 2016; Mell, 2017). These are also all subject to shifts due to political cycles, which makes planning for long-term funding more tenuous.

In addition to developing collaborations between LPAs, businesses, and the environmental sector, the most significant funding mechanism being explored are Parks Trusts. Liverpool, Newcastle and Sheffield have all explored parks trusts as a way of reducing costs from LPA balance sheets. Newcastle has progressed furthest, with NCC approving the formation of a charitable Parks Trust in November 2017. However, 
p. 149. Establishing the costs of poor green space management: mistrust, financing and future development options in the UK

there remain concerns from the public regarding the "transfer" of ownership of public assets to a non-publically accountable body. Moreover, in Liverpool and Newcastle, there is ongoing resistance to land sales and the creation of a tiered management system for green spaces. Moreover, in London there has also been an increasingly visible backlash against staging commercial events in public parks (Smith, 2017). Each of the aforementioned approaches to income generation is seen by some commentators as diminishing the value of public assets for private profit (Nesta, 2016). More positively we can identify the role of BIDs, particularly in London, as potential innovators in green infrastructure funding. Due to their position of authority within the business community they have been increasingly effective in generating funding and buy-in for investments in urban greening.

The range of options open to LPAs to fund green infrastructure is therefore expanding, as alternative public, private and community led approaches are explored. In each of the proposals noted there are positives in terms of lowering the financial and legal responsibilities for management but these are counter-balanced by concerns over the quality and extent of landscape protection within LPAs' activities. There does seem to be support for the development of Park Trusts in England, the testing of Park Improvement Districts, organisations based on a comparable model as BIDs and can use funding leveraged from local businesses to park for parks, and the use of Park Accelerator funding that can be used to develop new funding models (Neal, 2013; Nesta, 2016). In addition, in November 2018 the City of London Corporation announced that all new development in the financial heart of London would be required to deliver green infrastructure on-site as part of any planning consent (City of London Corporation, 2018). The application and success of each of these approaches, however, remain uncertain as each is currently being tested and requires additional analysis before being rolled out to other cities. Likewise, the promotion of BIDs as facilitators of green infrastructure have shown positive outcomes in London but more evidence is needed to assess whether BIDs can become key drivers of landscape investment in other cities.

Each of the approaches noted above provides scope to investigate the value of working with alternative funding mechanisms. However, the evidence base needed to support their use as appropriate and acceptable forms of financing green infrastructure remains less certain (Mell, 2017). Further research and evaluation of the benefits of each is, therefore, needed to convince LPAs and other stakeholders that they are appropriate in the delivery of green infrastructure.

We should not assume that any of these approaches to funding offers the solution to funding cuts. What they do offer, however, is an opportunity to recalibrate what green infrastructure is funded and how. As a consequence, potentially, the only positive outcome of austerity from a landscape perspective has been the requirement of LPAs to rethink their approaches to funding green infrastructure. The realisation that they will not be able to rely on central government grants to meet the costs of green space provision has opened up a wider ranging debate which assesses the value of alternative public, private, and community-led funding mechanisms. This has led to a more reflective assessment being made in terms of the costs of service provision, where cuts and modifications to management can be made, and importantly, how nontraditional stakeholders can be identified. However, this process is ongoing and illustrates the difficulties faced by LPAs in assessing the viability of alternative approaches in an era where environmental decision-making is being scrutinised more extensively to ensure transparency of action. 
p. 150. Establishing the costs of poor green space management: mistrust, financing and future development options in the UK

\section{Notes}

1 LPAs across the UK locate green infrastructure management within different departments. Consequently, green spaces have been discussed in terms of parks, gardens, landscape and community service management. Within this article "green infrastructure" is used as an overarching term covering each of these approaches. In text discussions consequently relate to either green infrastructure or green space management, as they are both frequently used terms. Where additional terminology is used, it reflects the language used by LPAs.

2 It should be noted that some commentators have also categorised New Labour as promoting a neo-liberalisation of government in the UK which led to an increased commercialisation of LPA functions and services (Allmendinger, 2011; Lord and Tewdwr-Jones, 2014).

3 Green infrastructure is defined as an interconnected network of green space that conserves natural ecosystem values and functions and provides associated benefits to human populations. Green infrastructure is the ecological framework needed for environmental, social and economic sustainability-in short [a] natural life sustaining system (Benedict and McMahon, 2002: 5).

4 Grey infrastructure are the non-ecological elements of the built environment pertaining to resources that serve little or no environmental function. It includes buildings, roads and other infrastructure. Where the built environment is greened, such as through the use of green walls and roofs or sustainable urban drainage systems, the value of urban infrastructure can be improved.

5 Post-industrial areas have been the delivery focus of England's Community Forest Partnehsips (2004) because they have been subject to socio-economic and ecological denudation, and are therefore prone to "territorial injustice" in the allocation of funding (Butler, 2018b) and institutional schizophrenia with regards to how LPAs distribute resources to address ecological marginalisation (Roe and Mell, 2013).

${ }^{6}$ Advocates of green infrastructure include the National Health Service (NHS), schools, local sports teams/clubs, environmental charities, community outreach programmes, businesses, and civic institutions (Landscape Institute, 2013; Naumann et al., 2011) and includes organizations that can make applications for grants from UK based charities and businesses, and strategic European level funding that cannot be leveraged by LPAs.

7 S106 Agreements or Community Infrastructure Levy (CIL) payments.

8 Valuing Nature Placement - Valuing green infrastructure for health in London's local government and business communities in conjunction with the GLA (2017/18).

9 Media outlets reviewed include the Liverpool Echo, Sheffield Star, Newcastle Chronicle. London Evening Standard, The Guardian and The Independent.

10 These include charging organisations a fee for an event licence, charging for car parking, entrance fees for sites and facilitating an increased number of businesses being located within the cities parks (Staples, 2018).

11 The potential benefits of the Parks Trust model were outlined in the LG\&OSR (2016) and debated with council officers who engaged with officers in Sheffield and Newcastle to debate the viability of this funding model (personal communications with council officials, 2016/17).

12 The EU Horizon 2020 programme is currently funding projects promoting NBS. The support of NBS builds on the research and delivery of green infrastructure but reflects 
p. 151. Establishing the costs of poor green space management: mistrust, financing and future development options in the UK

a change in terminology for EU funded initiatives. LCC may not have been in a position to join the consortium applying for funding if it had not undertaken the LG\&OSR, as this generated a significant level of support within the upper echelons of the council to deliver landscape improvement works. Investment in green infrastructure was, as a consequence, seen as a positive area to invest in (personal communications with council officials, 2017/18). This project received over $€ 3$ million to help implement and monitor green infrastructure in Liverpool, thus highlighting the political value of the LG\&OSR in providing an evidence base to generate additional grant funding.

13 In July 2018 NCC appointed a Chair for the Newcastle Parks Trust and released the names of the trustees who will run the Parks Trust (Newcastle City Council, 2018a, 2018b). The Parks Trust has been developed in conjunction with the Heritage Lottery Fund (HLF) and National Trust.

14 This figure is lower than the 400-hectare figure previously proposed.

15 Although this may not have been a public discussion SCC was liaising with LCC and NCC to explore the potential for a parks trust to be established in Sheffield (personal communication with LCC officer 2015/16).

16 The contractor's Private Finance Initiative (PFI) contract 'Street Ahead' was scheduled to run until 2037 (a 25-year agreement) at a cost of $£ 2.2$ billion. The contract includes the provision of road resurfacing works, replacement of street lamps, pavement works, and the management of approximately 36,000 street trees (Sheffield City Council, 2012).

17 Public safety and discrimination regarding use of footpaths have been proposed as two reasons for tree feeling to facilitate ease of movement for people with mobility/sight issues. However, the contract proposes a number of further issues: Dangerous, Dead, Diseased, Dying, Damaging or Discriminatory infrastructure that can be used to justify tree feeling (Sheffield City Council, 2012).

18 The information underpinning this analysis was derived from research undertaken for the Valuing Nature Partnership via a placement with the GLA in 2017/18. The commentary is drawn from a series of interviews with business, community-thirdenvironmental sector organisations that deliver landscape focused projects.

19 Stage 2 of the Plan for Thamesmead commenced in June 2018 with the aim of consulting local residents, businesses and communities of interest regarding the redevelopment of the area and the ways in which green infrastructure could be utilized to improve the areas livability.

\section{Acknowledgements}

The data collected and analysed within this article was partially funded by the Valuing Nature Programme via the Valuing Nature Placements scheme undertaken in 2017/18 with the Greater London Authority. It has also been supported through engagement with the Liverpool Green and Open Space Review (LG\&OSR) process by the author and a continuation of this relationship with Liverpool City Council via the Horizon 2020 Urban GreenUP programme. I would also like to thank the reviewers and editors for their comments that helped to shape the article.

* Correspondence address: Dr lan Mell, School of Environment, Education and Development, University of Manchester, M13 9PL. Email: ian.mell@manchester.ac.uk 
p. 152. Establishing the costs of poor green space management: mistrust, financing and future development options in the UK

\section{Bibliography}

Allmendinger, P. (2011) New Labour and Planning: From New Right to New Left. Abingdon: Routledge.

Benedict, M. A., and McMahon, E. T. (2002) Green Infrastructure: Smart Conservation for the 21st Century. Renewable Resources Journal, Autumn Edi, 12-17.

Bentley, G. and Pugalis, L. (2013) New directions in economic development: Localist policy discourses and the Localism Act. Local Economy, 28, 3, 257-274. Available at: https://doi.org/10.1177/0269094212473940

Blackman, D. and Thackray, R. (2007) The Green Infrastructure of Sustainable Communities. North Allerton: England's Community Forest Partnerships.

Broomfield, M. (2017) Hundreds of English playgrounds have been closed due to Tory budget cuts. Independent Online. Available at: https://www.independent.co.uk/news/uk/politics/playgrounds-closed-englandconservative-budget-cuts-tory-government-children-public-spaces-councilsa7682141.html

Burn, C. (2017) Sheffield Council 'would consider ending PFI contract after tree furore.' The Yorkshire Post Online. Available at: https://www.yorkshirepost.co.uk/news/sheffield-council-would-consider-endingpfi-contract-after-tree-furore-1-8890732

Butler, P. (2018a) Northamptonshire council backs "bare minimum" service plan. The Guardian Online. Available at: https://www.theguardian.com/society/2018/aug/09/northamptonshire-councilbacks-bare-minimum-service-plan

Butler, P. (2018b) "Territorial injustice" may rise in England due to council cuts - study. The Guardian Online. Available at: https://www.theguardian.com/society/2018/oct/09/territorial-injustice-on-riseengland-due-to-council-cuts-study

Caller, M. (2018) Northamptonshire County Council Best Value Inspection. January March 2018. London.

City of London Corporation. (2018) City of London Corporation maps out the Square Mile's future development. Available at: https://news.cityoflondon.gov.uk/city-ofIondon-corporation-maps-out-the-square-miles-future-development/ [Accessed: 05/11/2018]

Clarke, N. and Cochrane, A. (2013) Geographies and politics of localism: The localism of the United Kingdom's coalition government. Political Geography, 34, 10-23.

Cosgrove, S. (2017) Newcastle wins HLF funding to help it develop parks trust model. Horticulture Weekly Online. Available at: https://www.hortweek.com/newcastlewins-hlf-funding-help-develop-parks-trust-model/parks-andgardens/article/1424037

Cosgrove, S. (2018) How landscape will drive the regeneration of London's Thamesmead development. Horticulture Weekly Onlinec. Available at: https://www.hortweek.com/landscape-will-drive-regeneration-londonsthamesmead-development/landscape/article/1488878

Countryside Agency and Groundwork (2005) The Countryside in and around towns: A vision for connecting town and county in the pursuit of sustainable development. Wetherby: Countryside Agency.

Cross River Parnership and Natural England (2016) Green Capital: Green Infrastructure for a future city. London: Corss River Partnership.

De Magalhães, C. (2012) Business Improvement Districts and the recession: Implications for public realm governance and management in England. Progress in Planning, 77, 4, 143-177. Available at: https://doi.org/10.1016/J.PROGRESS.2012.03.002 
p. 153. Establishing the costs of poor green space management: mistrust, financing and future development options in the UK

Department for Environment Farming and Rural Affairs (2018) A Green Future: Our 25 Year Plan to Improve the Environment. London: Defra.

Department of Communities and Local Government (2012) National Planning Policy Framework. London: DCLG.

Department of Communties and Local Government (2011) A Plain English Guide to the Localism Act. London: DCLG.

Department of Environment Transport and the Regions (1999) Towards an Urban Renaissance. London: DETR.

Duncan, T. and Hussain, F. (2017a) Creating a Charitable Trust to Protect Newcastle's Parks and Allotments. Cabinet Report 20th November 2017. Newcastle.

Duncan, T. and Hussain, F. (2017b) Development of a Charitable Trust to Deliver Newcastle's Parks and Open Spaces. Cabinet Report 17th July 2018. Necastle.

Ecotec and Sheffield Hallam University (2013) Green Infrastructure's contribution to economic growth: A Review. Sheffield: Ecotec.

Eichler, W. (2018) London boroughs 'hard hit' by austerity, think tank says. Available at: https://www.localgov.co.uk/London-boroughs-hard-hit-by-austerity-think-tanksays/45257 [Accessed: 18/10/2018]

England's Community Forests (2004) Quality of Place, Quality of Life. Newcastle: England's Community Forest Parrtnership.

Fitzgerald, A. and Lupton, R. (2015) The Limits of Resilience? The Impact of Loca Government Spendfing Cuts in London. Local Government Studies, 41, 582-600.

Gaffikin, F., Mceldowney, M. and Sterrett, K. (2010) Creating Shared Public Space in the Contested City: The Role of Urban Design. Journal of Urban Design, 15, 4, 493-513. Available at: https://doi.org/10.1080/13574809.2010.502338

Gainsbury, S. and Neville, S. (2015) Austerity's $£ 18 \mathrm{bn}$ impact on local services. Financial Times Online. Available at: https://www.ft.com/content/5fcbdOc42948-11e5-8db8-c033edba8a6e [Accessed: 19/07/2018]

Gill, S. E., Handley, J. F., Ennos, A. R. and Pauleit, S. (2007) Adapting Cities for Climate Change: The Role of the Green Infrastructure. Built Environment, 33, 1, 115-133. DOI: 10.2148/benv.33.1.115

Greater London Authority (2015) Natural Capital Investing in a Green Infrastructure for a Future London. London: GLA.

Greater London Authority (2016) The London Plan: The Spatial Development Strategy for London consolidated with alterartions since 2011. London: GLA.

Grosvenor (2015) Living Cities: Our approach in practice. London: Grosvenor.

Henderson, T. (2017) Newcastle parks shake-up: People fear for future of city's green spaces. The Chronicle Live. Available at https://www.chroniclelive.co.uk/news/north-east-news/newcastle-parks-shakeup-people-12903240

Heritage Lottery Fund (2016) State of UK Public Parks 2016. London: HLF.

Highways (2012) Amey wins £2bn Sheffield highways deal. Available at: https://www.highwaysmagazine.co.uk/Amey-wins-2bn-Sheffield-highwaysdeal/314 [Accessed: 19/10/2018]

Hislop, M. and Corbett, A. (2018) Green Infrastructure Policies in the CSGN A Review of Local Authority Policies on Green Infrastructure in Built Development. Glasgow: The GCV Green Network Partnership.

Holland, D. (2018) Newcastle City Council to pay headhunter $£ 18,000$ after failing to find parks trust boss. The Chronicle Live. Available at: https://www.chroniclelive.co.uk/news/north-east-news/newcastle-city-councilpay-headhunter-14585708 [Accessed: 27/04/2018]

Horwood, K. (2011) Green infrastructure : reconciling urban green space and regional economic development: lessons learnt from experience in England's north-west region. Local Environment: The International Journal of Justice and Sustainability, 16, 10, 37-41. 
p. 154. Establishing the costs of poor green space management: mistrust, financing and future development options in the UK

Houghton, A. (2018) Walton Hall Park campaigners furious at land "sell-off plan" - but city chiefs say it's a mistake. Liverpool Echo Online. Available at: https://www.liverpoolecho.co.uk/news/liverpool-news/walton-hall-parkcampaigners-furious-14344303

Howard, E. (2009) Garden Cities of To-Morrow (Illustrated Edition) (Dodo Press) Gloucester: Dodo Press.

Jerome, G., Mell, I.C. and Shaw, D. (2017) Re-defining the characteristics of environmental volunteering: Creating a typology of community-scale green infrastructure. Environmental Research, 158, 399-408. Available at: https://doi.org/10.1016/j.envres.2017.05.037

Kambites, C. and Owen, S. (2006) Renewed prospects for green infrastructure planning in the UK. Planning Practice and Research, 21, 4, 483-496.

Lally, K. (2018) CONFIRMED: Nearly fifty green belt sites WILL be opened to development. Liverpool Echo online. Available at: https://www.liverpoolecho.co.uk/news/liverpool-news/confirmed-nearly-fiftygreen-belt-14942973 [03/12/2018]

Landscape Institute (2013) Green Infrastructure - An integrated approach to land use. Landscape Institute Position Statement. London: Landscape Institute.

Lennon, M. (2014) Green infrastructure and planning policy: a critical assessment. Local Environment, 20, 8, 957-980.

Lennon, M., Scott, M., Collier, M. and Foley, K. (2015) Developing green infrastructure 'thinking': devising and applying an interactive group-based methodology for practitioners. Journal of Environmental Planning and Management, 1-23.

Liverpool City Council (2016) Strategic Green and Open Spaces Review Board: Final Report. Liverpool: LCC.

Liverpool Echo (2015a) Green space campaigners plan demonstration following consultation meeting. Available at: http://www.liverpoolecho.co.uk/news/greenspace-campaigners-plan-demonstration-8932492 [Accessed: 16/09/2015]

Liverpool Echo (2015b) Newsham Park among recreation grounds to be axed from list of possible development sites in Liverpool. Available at: http://www.liverpoolecho.co.uk/news/liverpool-news/newsham-park-amongrecreation-grounds-9937639\#ICID=sharebar_twitter [Accessed: 16/09/2015]

Lloyd, M.G., McCarthy, J., McGreal, S. and Berry, J. (2003) Business Improvement Districts, Planning and Urban Regeneration. International Planning Studies, 8, 4, 295-321.

Local Government Association (2014) Under pressure How councils are planning for future cuts Corporate. London: LGA. Available at: https://www.local.gov.uk/sites/default/files/documents/under-pressure-howcounci-471.pdf

Lord, A. and Tewdwr-Jones, M. (2014) Is Planning "Under Attack"? Chronicling the Deregulation of Urban and Environmental Planning in England. European Planning Studies, 22, 2, 345-361. Available at: https://doi.org/10.1080/09654313.2012.741574

Lowndes, V. and Gardner, A. (2016) Local governance under the Conservatives: superausterity, devolution and the 'smarter state.' Local Government Studies, 42, 3, 357-375. Available at: https://doi.org/10.1080/03003930.2016.1150837

Lowndes, V. and Pratchett, L. (2012) Local Governance under the Coalition Government: Austerity, Localism and the 'Big Society.' Local Government Studies, 38, 1, 21-40. Available at: https://doi.org/10.1080/03003930.2011.642949

Marshall, T. (2009) Planning and New Labour in the UK. Planning Practice and Research, 24, 1, 1-9.

Martin, R., Pike, A., Tyler, P. and Gardiner, B. (2016) Spatially Rebalancing the UK Economy: Towards a New Policy Model? Regional Studies, 50, 2, 342-357. Available at: https://doi.org/10.1080/00343404.2015.1118450 
p. 155. Establishing the costs of poor green space management: mistrust, financing and future development options in the UK

Mayor of London (2016) The London Plan - The Spatial Development Strategy for London consoliated with alterations since 2011. London: Mayor of London. Available

at: https://doi.org/https://www.london.gov.uk/sites/default/files/the_london_plan_ 2016_jan_2017_fix.pdf

McGuinness, D. and Mawson, J. (2017) The rescaling of sub-national planning: can localism resolve England's spatial planning conundrum? Town Planning Review, 88, 3, 283-303. Available at: https://doi.org/10.3828/tpr.2017.19

Meerow, S. and Newell, J. P. (2017) Spatial planning for multifunctional green infrastructure: Growing resilience in Detroit. Landscape and Urban Planning, 159, 62-75. Available at: https://doi.org/10.1016/j.landurbplan.2016.10.005

Mell, I. (2017) Financing the future of green infrastructure planning: alternatives and opportunities in the UK. Landscape Research, 43, 6, 751-768. Available at: https://doi.org/10.1080/01426397.2017.1390079

Mell, I.C. (2010) Green infrastructure: concepts, perceptions and its use in spatial planning. Unpublished PhD Thesis, University of Newcastle.

Mell, I.C. (2014) Aligning fragmented planning structures through a green infrastructure approach to urban development in the UK and USA. Urban Forestry and Urban Greening, $13,4,612-620.4$ Available https://doi.org/10.1016/j.ufug.2014.07.007

Mell, I.C. (2015) Green infrastructure planning: policy and objectives. In: Sinnett, D., Burgess, S. and Smith, N. (Eds.), Handbook on Green Infrastructure: Planning, design and implementation (pp. 105-123). Cheltenham: Edward Elgar Publishing Ltd.

Mell, I.C. (2016) Global Green frastructure: Lessons for successful policy-making, investment and management. Abingdon: Routledge.

Mell, I.C., Henneberry, J., Hehl-Lange, S. and Keskin, B. (2016) To green or not to green: Establishing the economic value of green infrastructure investments in The Wicker, Sheffield. Urban Forestry and Urban Greening, 18, 257-267. Available at: https://doi.org/10.1016/j.ufug.2016.06.015

Mersey Forest (2013) The Mersey Forest Plan: Final Draft, September 2013. Risley Moss: The Mersey Forest.

Moore, R. (2017) The end of parklife as we know it? The battle for Britain's green spaces. The Guardian. Available at: https://www.theguardian.com/uknews/2017/jul/09/the-end-of-park-life-as-we-know-it-the-battle-for-britains-greenspaces-rowan-moore

Naumann, S., Davis, M., Kaphengst, T., Pieterse, M. and Rayment, M. (2011) Design, implementation and cost elements of Green Infrastructure projects. Final report to the European Commission, DG Environment, Contract no. 070307/2010/577182/ETU/F.1. Berlin: The Resilience Alliance.

Naylor, L., Kippen, H., Coombes, M., Horton, B., MacArthur, M. and Jackson, N. (2017) Greening the Grey: a framework for integrated green grey infrastructure (IGGI). Glasgow: Universirty of Glasgow.

Neal, P. (2013) Rethinking Parks: exploring new business models for parks in the 21st century. London: Nesta.

Nesta (2016) Learning to rethink parks. London: Nesta.

Nesta (2018) Heeley Subscription Society. Available at: https://www.nesta.org.uk/project/rethinking-parks/heeley-subscriptionsociety/[Accessed: 31/10/2018]

Newcastle City Council (2018a) Meet the Parks Trust. Available at: https://www.newcastle.gov.uk/leisure-libraries-and-tourism/parks-andcountryside/future-newcastles-parks-and-allotments/meet-parks-trust [Accessed: 18/10/2018] 
p. 156. Establishing the costs of poor green space management: mistrust, financing and future development options in the UK

Newcastle City Council (2018b) Newcastle's pioneering Parks Trust appoints founding Chair and Board of Trustees. Available at: https://www.newcastle.gov.uk/news/newcastles-pioneering-parks-trust-appointsfounding-chair-and-board-trustees [Accessed: 18/10/2018]

O'Brien, P. and Pike, A. (2015) City Deals, Decentralisation and the Governance of Local Infrastructure Funding and Financing in the UK. National Institute Economic Review, 233, 1, R14-R26. Available at: https://doi.org/10.1177/002795011523300103

Office of the Deputy Prime Minister (2002) Sustainable Communities - Delivering through Planning. London: ODPM.

Papworth, T. (2015) The Green Noose: An analysis of Green Belts and proposals for reform. Adam Smith Institute, London.

Perraudin, F. (2018) Sheffield MPs urge council to pause tree felling. The Guardian Online. Available at: https://www.theguardian.com/uknews/2018/mar/15/sheffield-mps-urge-council-to-pause-tree-felling

Plimmer, G. (2016) UK parks endangered by council spending cuts, MPs warned. Financial Times Online. Available at: https://www.ft.com/content/39164258 8634-11e6-a29c-6e7d9515ad15

Pretty, J., Peacock, J., Hine, R., Sellens, M., South, N. and Griffin, M. (2007) Green exercise in the UK countryside: Effects on health and psychological well-being, and implications for policy and planning. Journal of Environmental Planning and Management, 50, 2, 211-231.

Raco, M. (2005) Sustainable Development, Rolled-out Neoliberalism and Sustainable Communities. Antipode, 37, 2, 324-347. Available at: https://doi.org/10.1111/j.0066-4812.2005.00495.x

Roe, M. and Mell, I.C. (2013) Negotiating value and priorities : evaluating the demands of green infrastructure development. Journal of Environmental Planning and Management, 56, 5, 37-41.

Seddon, S. (2017) What is green belt land? And how come North East councils are building on it? The Chronicle Live. Available at: https://www.chroniclelive.co.uk/news/north-east-news/what-green-belt-land-how13348444

Selman, P. (2009) Planning for landscape multifunctionality. Sustainability: Science, Practice and Policy, 5, 2, 45-52.

Sheffield City Council (2017) Council faces seventh year of budget cuts. Available at: https://sheffieldnewsroom.co.uk/news/budget-cuts-1718/ [Accessed: 19/10/2018]

Sheffield City Council (2012) (1) The Sheffield City Council and (2) Amey Hallam Highways Limited. CONTRACT relating to the rehabilitation, maintenance, management and operation of the highway assets in the Area pursuant to the Government's Private Finance Initiative. Sheffield: SCC. Retrieved from https://www.sheffield.gov.uk/content/dam/sheffield/docs/roads-andpavements/streetsahead/Contract.pdf [Accessed: 19/10/2018]

Sinnett, D., Smith, N. and Burgess, S. (2015) Handbook on Green Infrastructure: Planning, design and implementation. Cheltenham: Edward Elgar Publishing Ltd.

Smith, A. (2017) Animation or Denigration? Using Urban Public Spaces as Event Venues. Event Management, 21, 5, 609-619. Available at: https://doi.org/10.3727/152599517X15053272359068

Staples, J. (2018) The Purpose of Report to Approve a New Animation Policy for Events Held in Parks and Other Areas of Public Realm. Meeting of Neighbourhoods Select Committee, Tuesday 8th February (Item 74). Liverpool: LCC.

Tait, M. (2011) Trust and the Public Interest in the Micropolitics of Planning Practice. Journal of Planning Education and Research, 31, 2, 157-171. Available at: https://doi.org/10.1177/0739456X11402628 
p. 157. Establishing the costs of poor green space management: mistrust, financing and future development options in the UK

Taylor, M. (2018) “Time running out” for UK parks, government told. The Guardian Online. Available at: https://www.theguardian.com/environment/2018/jun/21/time-running-out-foruk-parks-government-told

Tewdwr-Jones, M. (2012) Spatial Planning and Governance: Understanding UK Planning. Basingstoke: Palgrave Macmillan.

Thames21 (2016) Championing the river: 2016-2021 Five Year Plan. London: Thames21.

Thomas, K. and Littlewood, S. (2010) From Green Belts to Green Infrastructure? The Evolution of a New Concept in the Emerging Soft Governance of Spatial Strategies. Planning Practice and Research, 25, 2, 203-222.

Thorp, L. (2018) Sefton Park Meadows is SAVED - Mayor Joe says no houses to be built. Liverpool Echo Online. Available at: https://www.liverpoolecho.co.uk/news/liverpool-news/sefton-park-meadowssaved-mayor-14177925

Torr, G. (2018) Sheffield taxpayers to continue to pay off Amey PFI deal "20 years after contract finishes." The Star Online. Available at: https://www.thestar.co.uk/news/sheffield-taxpayers-to-continue-to-pay-off-ameypfi-deal-20-years-after-contract-finishes-1-8959486

Tzoulas, K. and James, P. (2010) Peoples' use of, and concerns about, green space networks: A case study of Birchwood, Warrington New Town, UK. Urban Forestry \& Urban Greening, 9, 2, 121-128. Available at: https://doi.org/10.1016/j.ufug.2009.12.001

Vivid Economics (2016) The contribution made by Sheffield's parks to the wellbeing of the city's citizens. London: Vivid Economics.

Walmsley, A. (2006) Greenways: multiplying and diversifying in the 21st century. Landscape and Urban Planning, 76, 1-4, 252-290.

Ward, K. (2006) "Policies in Motion", Urban Management and State Restructuring: The Trans-Local Expansion of Business Improvement Districts. International Journal of Urban and Regional Research, 30, 1, 54-75. Available at: https://doi.org/10.1111/j.1468-2427.2006.00643.x

Wilson, O. and Hughes, O. (2011) Urban Green Space Policy and Discourse in England under New Labour from 1997 to 2010. Planning Practice and Research, 26, 2, 207-228.

Wolch, J.R., Byrne, J. and Newell, J.P. (2014) Urban green space, public health, and environmental justice: The challenge of making cities 'just green enough.' Landscape and Urban Planning, 125, 234-244. Available at: https://doi.org/10.1016/j.landurbplan.2014.01.017 